Tropical Journal of Pharmaceutical Research May 2017; 16 (5): 1137-1146

ISSN: $1596-5996$ (print); 1596-9827 (electronic)

(C) Pharmacotherapy Group, Faculty of Pharmacy, University of Benin, Benin City, 300001 Nigeria.

All rights reserved.

Available online at http://www.tjpr.org

Original Research Article

http://dx.doi.org/10.4314/tjpr.v16i5.23

\title{
Synthesis, characterization and pharmacological evaluation of mixed ligand-metal complexes containing omeprazole and 8-hydroxyquinoline
}

\author{
Waqar Ahmad ${ }^{1}$, Shakeel Ahmad Khan ${ }^{2 \star}$, Khurram Shahzad Munawar ${ }^{1}$, Asma \\ Khalid $^{3}$ and Sadia Kawanl ${ }^{4}$ \\ ${ }^{1}$ Department of Chemistry, University of Management and Technology, Lahore-54000, Pakistan, ${ }^{2}$ Department of chemistry, \\ Hallym University, Chuncheon, Gangwon-do, 200-702, Republic of Korea, ${ }^{3}$ Institute of Chemistry, University of the Punjab, \\ Lahore-54590, ${ }^{4}$ Department of Biochemistry, University of Agriculture, Faisalabad-38000, Pakistan
}

*For correspondence: Email: Shakilahmad56@gmail.com; Tel: 01032692977

Sent for review: 24 January 2017

Revised accepted: 15 April 2017

\begin{abstract}
Purpose: To synthesize a series of mixed ligand-metal complexes and to evaluate their alkaline phosphatase inhibitory capacities, antioxidant potential and antimicrobial activities.

Method: Mixed ligand-metal complexes of Zn (II), Ni (II), Co (II), Cu (II), omeprazole and 8hydroxyquinoline were synthesized. The ligand-metal complexes were characterized by various physicochemical techniques, including elemental analysis, magnetic susceptibility, scanning electron microscope (SEM), mass spectrometry (EI-MS), ultraviolet-visible (UV-Vis) spectrophotometry, Fourier transform infrared spectroscopy (FTIR), proton nuclear magnetic resonance ( $H$-NMR) and conductance studies. The new compounds were also investigated for their alkaline phosphatase (ALPS) inhibition, 2,2'-diphenyl-1-picrylhydrazyl (DPPH) radical-scavenging and antimicrobial activities.

Results: Spectroscopic studies revealed the chemical composition of synthesized compounds as well as the bidentate bonding behavior of the coordinating ligands with metal ions. Conductance measurement suggested that the metal complexes were non-electrolytes. Ni(II) complex exhibited antioxidant activity $(30.48 \pm 0.32 \mu \mathrm{M})$ higher than those of BHT (standard) and other complexes. Stronger inhibition of ALPS by Ni (II) mixed ligand complex compared to the other complexes was evident. The synthesized compounds showed moderate to very good antimicrobial activity against bacterial strains, i.e., Escherichia coli, Pseudomonas aeruginosa, Klebsiella pneumoniae, Actinomyces viscosus, Staphylococcus aureus, Bacillus subtilis; as well as against the fungal strains, Candida albicans, Aspergillus flavus and Aspergillus niger.

Conclusion: All the mixed ligand complexes demonstrate higher antioxidant, ALPs-inhibitory and antimicrobial activities than their corresponding ligands. This indicates their therapeutic potential as future drug candidates for the concerned diseases.
\end{abstract}

Keywords: Omeprazole, 8-Hydroxyquinoline, Mixed-ligand complexes, Alkaline phosphatase, Bidentate bonding behaviors

Tropical Journal of Pharmaceutical Research is indexed by Science Citation Index (SciSearch), Scopus, International Pharmaceutical Abstract, Chemical Abstracts, Embase, Index Copernicus, EBSCO, African Index Medicus, JournalSeek, Journal Citation Reports/Science Edition, Directory of Open Access Journals (DOAJ), African Journal Online, Bioline International, Open-J-Gate and Pharmacy Abstracts

\section{INTRODUCTION}

Omeprazole belongs to a class of substituted benzimidazole and has some clinical applications in treatment of peptic-acid diseases like gastric and esophageal ulceration and prevention of their relapse [1]. Acid inhibition strategies such as histamine $\mathrm{H}_{2}$-receptor antagonist and use of 
anti-cholinergic agents have been employed to treat peptic ulcer disease. Omeprazole is a proton pump inhibitor which promotes reduction of parietal cells by a series of prototropic reactions. The long duration of action of parietal cell $\mathrm{H}^{+}-\mathrm{K}^{+}$-ATPase is due to prolonged binding of the active form of the drug [2-4]. Omeprazole has a privileged structure in pharmacophore and medicine chemistry. The importance of this compound is due to its bicyclic structure which is a fusion of benzene and imidazole rings. The plasma elimination half-life $\left(t_{1 / 2 \beta}\right)$ of omeprazole is usually shorter than one hour, although a few individuals exhibit slower elimination ( $\mathrm{t}_{1 / 2 \beta} \approx 2 \mathrm{~h}$ ). These individuals have recently been shown to be poor hydroxylators of S-mephenytoin, which suggests that a major part of omeprazole metabolism is mediated by S-mephenytoin hydroxylase, an enzyme within the cytochrome P450 system $[5,6]$.

Omeprazole is completely metabolized and its average plasma clearance is $30 \mathrm{~L} / \mathrm{h}$. The drug also shows good antimicrobial activity against Helicobacter pylori [7-9]. 8-hydroxyquinoline is well-known for its antimicrobial activity. It has been comprehensively used for analytical determination of metal ions [10]. Cheatum et al [11] studied the dynamic excited state of $\mathrm{HQL}$ dimmers.

In the present study, an attempt has been made to synthesize $\mathrm{Zn}$ (II), $\mathrm{Co}(\mathrm{II}), \mathrm{Ni}(\mathrm{II})$ and $\mathrm{Cu}$ (II) mixed ligand complexes of omeprazole and 8hydroxyquinoline. All the complexes were characterized by spectroscopic techniques and their biological activities were studied.

\section{EXPERIMENTAL}

All chemicals and solvents of analytical grade were purchased from Merck and Sigma-Aldrich. UV-visible spectra were recorded from 200 - 800 $\mathrm{nm}$ on Jasco UV visible spectrophotometer model V-770 UV-VIS. FT-IR spectra were recorded on Nicolet IS50, FT-IR spectrophotometer from 400-4000 cm $\mathrm{cm}^{-1}$. Elemental analyses were performed on a CHNS/O-2400 Series II elemental analyzer. Magnetic susceptibility was determined using Holmarc's Magnetic Susceptibility (model HOED-EM-07). Mass spectral measurement was performed on Finnigan MAT LCQ ${ }^{\mathrm{TM}}$ mass spectrometer. The molar conductance of the synthesized complexes in DMSO was measured using a Conductivity Meter, Model WD-35604-00 at $25{ }^{\circ} \mathrm{C}$ temperature. SEM images were recorded in a Hitachi SEM analyzer. ${ }^{1} \mathrm{H}-\mathrm{NMR}$ spectra were recorded in DMSO- $d_{6}$ at room temperature using TMS as internal standard on a Bruker $400 \mathrm{MHz}$ spectrophotometer.

\section{Synthesis of mixed ligand metal complexes}

Mixed ligand complexes were synthesized by mixing water-ethanol solutions $(1: 1, \mathrm{v} / \mathrm{v})$ of metal salts $(1 \mathrm{mmol})$, ethanolic solution of primary ligand (L) omeprazole $(0.345 \mathrm{~g}, 1 \mathrm{mmol})$ and secondary ligands 8-hydroxyquinoline (L2, 0.145 $\mathrm{g}, 1 \mathrm{mmol}$ ) in molar ratio of 1:1:1 (M:L:L2). The resultant mixture was refluxed for $3-4 \mathrm{~h}$ and colored precipitates were obtained in each case. The solids precipitated were filtered and washed with diethyl ether-ethanol $(1: 1 \mathrm{v} / \mathrm{v})$. Stability constants were also calculated. Figure 1 shows the structural formula of the mixed ligand metal complexes.

\section{Assay of inhibitory effects of metal complexes on ALPs}

The assay of inhibition of ALPs was done spectrophotometrically as described earlier [12]. Working substrate was prepared by mixing four parts of diethanolamine $\left(\mathrm{pH}=9.8,2 \mathrm{~mol} / \mathrm{dm}^{3}\right)$ and $\mathrm{MgCl}_{2}\left(0.5 \mathrm{mmol} / \mathrm{dm}^{3}\right)$, and one part of $p$ NPP $\left(50 \mathrm{mmol} / \mathrm{dm}^{3}\right)$. This substrate was incubated at $37^{\circ} \mathrm{C}$ for $5 \mathrm{~min}$. The ALP assay of OMZ, HQL and metals complexes were determined by addition of $2 \mathrm{~mL}$ of working substrate to $40 \mu \mathrm{L}$ of human serum.

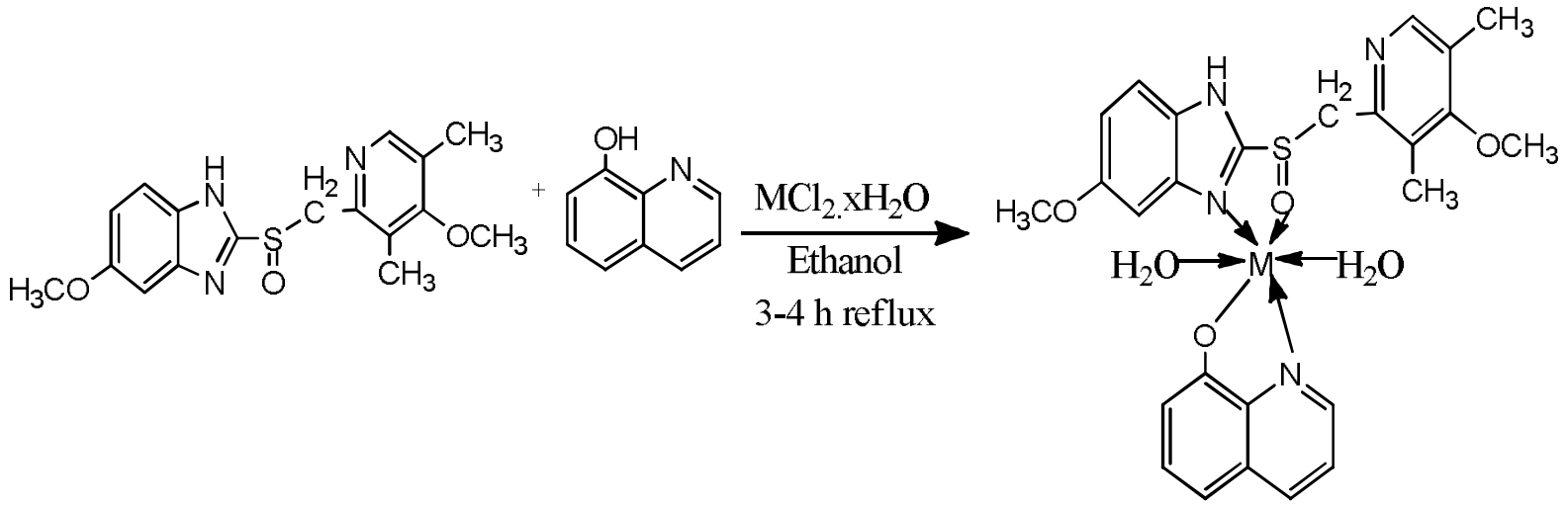

Figure 1: Reaction mechanism of mixed ligand metal complexes. ( $\mathrm{M}=\mathrm{Zn}(\mathrm{II}), \mathrm{Ni}(\mathrm{II}), \mathrm{Co}(\mathrm{II})$ and $\mathrm{Cu}(\mathrm{II}))$ 
ALP activity was assayed with $25 \mathrm{mM}$ stock solutions of $\mathrm{OMZ}, \mathrm{HQL}$ and the synthesized complexes. After the incubation period, absorbance was recorded at $405 \mathrm{~nm}$ [13]. All measurements were done in triplicate and the mean of these values was used to calculate the percentage inhibition of ALPs activity. The principle of this assay is that colorless $p$ Nitrophenyl phosphate (substrate) in alkaline medium changes to a yellow-colored due to liberation of $p$-Nitrophenol by ALPS.

\section{Determination of DPPH radical scavenging activity}

DPPH free radical scavenging activity is a rapid technique for assay of antioxidant activities of compounds. Using the method as described by Khan et al [14] the DPPH free radical scavenging potential of the mixed ligand complexes were determined relative to standard i.e. butylated hydroxytoluene (BHT). In the assays, OMZ, HQL and synthesized mixed ligand metals complexes at various concentrations (500, 250, 125 and 60 $\mu \mathrm{g} / \mathrm{mL}$ ) were incubated with $3 \mathrm{ml}$ of $0.1 \mathrm{mM}$ $\mathrm{DPPH}$ in methanol for $60 \mathrm{~min}$ at room temperature. Absorbance was measured at 517 $\mathrm{nm}$ against methanol. The absorbance was decreased by conversion of DPPH to the more stable $\mathrm{DPPH}_{2}$ molecules, which serves as an indication of the capacity of antioxidant compounds to donate hydrogen ion [15]. All measurements were taken in triplicates. DPPH radical scavenging activity was calculated using the formula:

DPPH scavenging $(\%)=\{($ Ac - As $) / A c\} 100 \ldots$

where $A c$ is the absorbance of control and As is the absorbance of tested compounds.

\section{Antimicrobial assay}

The antimicrobial properties of OMZ, HQL and synthesized complexes were determined using the agar-well diffusion method [16]. Six bacterial strains including three Gram-negative strains, Klebsiella pneumoniae, Pseudomonas aeruginosa, Escherichia coli, and three Grampositive strains, Actinomyces viscosus, Staphylococcus aureus, and Bacillus subtilis were used. Antifungal activity was determined against Candida albicans, Aspergillus nigar and Aspergillus flavus. The culture media was prepared by dissolving $28 \mathrm{~g}$ of nutrient agar in $1 \mathrm{~L}$ of distilled water (for bacterial strains), and $38 \mathrm{~g}$ of potato dextrose agar in $1 \mathrm{~L}$ of distilled water for fungi. The media were autoclaved at $121^{\circ} \mathrm{C}$ and $15 \mathrm{LD} / \mathrm{sq}$ inch for $15 \mathrm{~min}$. The stock solution (100 $\mu \mathrm{L}$ in each dish) was put into Petri dishes and then allowed to attain room temperature. The microorganisms were cultured and incubated for $24 \mathrm{~h}$ at $37^{\circ} \mathrm{C}$ (for bacterial cultures) and for $48 \mathrm{~h}$ at $28{ }^{\circ} \mathrm{C}$ (for fungal cultures) $[17,18]$. Zones of inhibition in specimen Petri dishes were measured in $\mathrm{mm}$ with venire caliper in $\mathrm{mm}$. The anti-fungal drug fluconazole and antibacterial drug ampicillin (100 $\mathrm{\mu g} / \mathrm{mL})$ were used as standard controls for comparison with the tested specimens under similar conditions. These assays were performed in triplicate, and the mean was taken as the final reading.

\section{Statistical analysis}

Analysis of data was carried out using Microsoft Excel-2016 software. All computations were executed in triplicate and the results were expressed as mean \pm SEM $(n=3)$. Antimicrobial, DPPH and ALP assays were computed with suitable dilutions for each sample and different statistical techniques such as Duncan multiple range method, one-way analysis of variance were used for analysis of data obtained from different samples. $P<0.05$ was taken as indicative of statistical significance.

\section{RESULTS}

The synthesized mixture of ligand complexes showed yields that ranged from good to excellent yield (up to $89 \%$ ). The purity of the complexes was checked by melting point determination. Sharp melting points were obtained with fairly pure complexes. Low values of conductance measurements suggested the non-electrolyte nature of synthesized mixed ligand metal complexes. The chemical structures of all the synthesized compounds were deduced with the aid of physical and spectroscopic methods. Physical data and elemental (CHNS/O) analysis of these complexes were in good agreement with the proposed formulae. The general reaction equation (2) for the synthesis of the complexes is shown in Eq 2.

$\mathrm{OMZ}+\mathrm{HQL}+\mathrm{MCl}_{2} \cdot n \mathrm{H}_{2} \mathrm{O}$

$\mathrm{M}(\mathrm{LL} 2) \cdot n \mathrm{H}_{2} \mathrm{O}+2 \mathrm{HCl}+\mathrm{H}_{2}$ $(2)$

where $\mathrm{M}=\mathrm{Zn}(\mathrm{II})(n=0) ; \mathrm{M}=\mathrm{Ni}(\mathrm{II}), \mathrm{Co}(\mathrm{II})$ and $\mathrm{Cu}(\mathrm{II})(n=2)$

\section{Zn (II) Complex}

Yield: $89 \%$; colour: White solid; m.p: 266-268 ${ }^{\circ} \mathrm{C}$; Molar conductance, $\Lambda_{\mathrm{m}}$ (in $10^{-3} \mathrm{M}$ DMSO): $5.6 \mathrm{ohm}^{-1} \mathrm{~cm}^{2} \mathrm{~mol}^{-1}$; $\mu_{\text {eff: }}$ 1.71; Stability constant: $11.647 \log \mathrm{K}(\mathrm{L} / \mathrm{mole})$; Selected IR $\left(\mathrm{KBr}, \mathrm{cm}^{-1}\right)$ : $(\mathrm{S}=\mathrm{O}): 1023 ;(\mathrm{C}=\mathrm{N})_{\text {bnz }}: 1555 ;(\mathrm{C}=\mathrm{N})_{\mathrm{HQL}}: 1632$; (CO): 1723; (M-O): 479; (M-N): 435. Electronic 
spectra $(\lambda \max$ in $\mathrm{nm}): 289,229 .{ }^{1} \mathrm{H}$ NMR (400 $\mathrm{MHz}, \delta$, DMSO- $\left.d_{6}\right): 11.23(\mathrm{~s}, 1 \mathrm{H}) ; 8.02,8.41$ (s, $2 \mathrm{H}) ; 7.00-7.34(\mathrm{~m}, 7 \mathrm{H}) ; 6.97(\mathrm{~d}, 1 \mathrm{H}) ; 4.69(\mathrm{~s}, 2 \mathrm{H}$, $\mathrm{CH}_{2}$-pyridine); 3.51 (s, $\left.6 \mathrm{H}\right) ; 2.16$ (d, 6H). Anal. Calc. for $\mathrm{C}_{26} \mathrm{H}_{25} \mathrm{~N}_{4} \mathrm{O}_{4} \mathrm{SZn}$ (MW: $554.95 \mathrm{~g} / \mathrm{mol}$ ): C, 56.27; H, 4.54; N, 10.10; S, 5.78; O, 11.53; Zn, $11.78 \%$ and Found: C, 56.36; H, 4.91; N, 10.19; $\mathrm{S}, 5.61 ; \mathrm{O}, 11.59 ; \mathrm{Zn}, 11.68 \%$; MS ( $\mathrm{m} / \mathrm{z}$, (relative abundance, \%)): $554\left[\mathrm{M}^{+}, 9.5\right]$.

\section{Co (II) Complex}

Yield: $77 \%$; colour: Light green; m.p: 249-251 ${ }^{\circ} \mathrm{C}$; Molar conductance, $\Lambda_{\mathrm{m}}$ (in $10^{-3} \mathrm{M}$ DMSO): $5.9 \mathrm{ohm}^{-1} \mathrm{~cm}^{2} \mathrm{~mol}^{-1}$; $\mu_{\text {eff }}: 3.21$; Stability constant: $11.421 \log \mathrm{K}(\mathrm{L} / \mathrm{mole}) ;$ Selected IR $\left(\mathrm{KBr}, v, \mathrm{~cm}^{-1}\right)$ : $(\mathrm{S}=\mathrm{O}): 1027 ;(\mathrm{C}=\mathrm{N})$ bnz: 1549; $(\mathrm{C}=\mathrm{N})_{8 \mathrm{HQ}}: 1635$; (CO): 1731; $\left(\mathrm{H}_{2} \mathrm{O}\right): 3600-2700 ;(\mathrm{M}-\mathrm{O}): 486$; (M$\mathrm{N})$ : 439. Electronic spectra $(\lambda \max$ in $\mathrm{nm}): 290$, 226. ${ }^{1} \mathrm{H}$ NMR (400 MHz, $\delta$, DMSO- $d_{6}$ ): 12.09 (s, $1 \mathrm{H})$; 8.03, 8.36 (s, 2H); 7.03-7.43 (m, 7H); 6.81 (d, $1 \mathrm{H}) ; 4.63$ (s, 2H, $\mathrm{CH}_{2}$-pyridine); 3.53 (s, 4H; $\left.2 \mathrm{H}_{2} \mathrm{O}\right) ; 2.11(\mathrm{~d}, 6 \mathrm{H})$. Anal. Calc. for $\mathrm{C}_{26} \mathrm{H}_{29} \mathrm{~N}_{4} \mathrm{O}_{6} \mathrm{SCo}$ (MW: $584.529 \mathrm{~g} / \mathrm{mol}$ ): C, 53.42; H, 5.00; N, 9.58; S, 5.49; O, 16.42; Co, $10.08 \%$ and found: C, 53.56; H, 4.91; N, 9.42; S, 5.69; O, 16.61; Co, $9.89 \%$. MS ( $\mathrm{m} / \mathrm{z}$, (relative abundance, $\%): 584\left[\mathrm{M}^{+}, 14.9\right]$.

\section{Ni (II) Complex}

Yield: $83 \%$; colour: Light Brown; m.p, 241-244 ${ }^{\circ} \mathrm{C}$; Molar conductance, $\Lambda_{\mathrm{m}}$ (in $10^{-3} \mathrm{M}$ DMSO): $5.7 \mathrm{ohm}^{-1} \mathrm{~cm}^{2} \mathrm{~mol}^{-1} ; \mu_{\text {eff }}: 3.42$; Stability constant: $10.567 \log \mathrm{K}(\mathrm{L} / \mathrm{mole})$; Selected IR $\left(\mathrm{KBr}, v, \mathrm{~cm}^{-1}\right)$ : $(\mathrm{S}=\mathrm{O}): 1032 ; \quad(\mathrm{C}=\mathrm{N})_{\text {bnz }}: 1534 ;(\mathrm{C}=\mathrm{N})_{8 \mathrm{HQ}}: 1637$; (CO): 1733; $\left(\mathrm{H}_{2} \mathrm{O}\right)$ : 3600-2700; (M-O): 488; (M$\mathrm{N})$ : 443. Electronic spectra $(\lambda \max$ in $\mathrm{nm})$ : 294, 223. ${ }^{1} \mathrm{H}$ NMR (400 MHz, $\delta$, DMSO- $d_{6}$ ): 11.23 (s, $1 \mathrm{H}) ; 8.03,8.41(\mathrm{~s}, 2 \mathrm{H}) ; 7.02-7.31(\mathrm{~m}, 7 \mathrm{H}) ; 6.99$ (d, $1 \mathrm{H}) ; 4.64$ (s, 2H, $\mathrm{CH}_{2}$-pyridine); 3.53 (s, $6 \mathrm{H}$ ); $3.48\left(\mathrm{~s}, 4 \mathrm{H}, 2 \mathrm{H}_{2} \mathrm{O}\right) ; 2.16(\mathrm{~d}, 6 \mathrm{H})$. Anal. Calc. for $\mathrm{C}_{26} \mathrm{H}_{29} \mathrm{~N}_{4} \mathrm{O}_{6} \mathrm{SNi}(\mathrm{MW}: 584.29 \mathrm{~g} / \mathrm{mol}$ ): $\mathrm{C}, 53.45 ; \mathrm{H}$, $5.00 ; \mathrm{N}, 9.59 ; \mathrm{S}, 5.49 ; \mathrm{O}, 16.43 ; \mathrm{Ni}, 10.05 \%$ and Found: C, 53.78; H, 4.93; N, 9.64; S, 5.44; O, 16.49; Ni, $10.16 \%$. MS ( $\mathrm{m} / \mathrm{z}$, (relative abundance, $\%): 584\left[\mathrm{M}^{+}, 12.3\right]$.

\section{$\mathrm{Cu}$ (II) Complex}

Yield: $88 \%$; colour: Yellowish white: m.p., 223$227{ }^{\circ} \mathrm{C}$; Molar conductance, $\Lambda_{\mathrm{m}}$ (in $10^{-3} \mathrm{M}$ DMSO): $\quad 5.6 \quad \mathrm{ohm}^{-1} \mathrm{~cm}^{2} \mathrm{~mol}^{-1}$; Magnetic susceptibility, $\mu_{\text {eff }}: 3.79$; Stability constant: 11.289 $\log \mathrm{K}(\mathrm{L} / \mathrm{mole})$; Selected IR $\left(\mathrm{KBr}, v, \mathrm{~cm}^{-1}\right)$ : $(\mathrm{S}=\mathrm{O})$ : 1028; $(\mathrm{C}=\mathrm{N})_{\text {bnz }}: 1559 ; \quad(\mathrm{C}=\mathrm{N})_{8 \mathrm{HQ}}: 1623 ;(\mathrm{CO})$ : 1727; $v\left(\mathrm{H}_{2} \mathrm{O}\right)$ : 3600-2700; $v(\mathrm{M}-\mathrm{O}): 483 ; v(\mathrm{M}-\mathrm{N})$ : 449. ${ }^{1} \mathrm{H}$ NMR (400 MHz, $\delta$, DMSO- $\left.d_{6}\right): 11.23$ (s, $1 \mathrm{H}) ; 8.05,8.44(\mathrm{~s}, 2 \mathrm{H}) ; 7.02-7.71(\mathrm{~m}, 7 \mathrm{H}) ; 6.91$ (d, $1 \mathrm{H}) ; 4.68$ (s, 2H, $\mathrm{CH}_{2}$-pyridine); 3.59 (s, $6 \mathrm{H}$ ); $3.42\left(\mathrm{~s}, 4 \mathrm{H}, 2 \mathrm{H}_{2} \mathrm{O}\right) ; 2.16(\mathrm{~d}, 6 \mathrm{H})$. Electronic spectra $(\lambda \max$ in $\mathrm{nm}): 343,227$ Anal. Calc. for $\mathrm{C}_{26} \mathrm{H}_{29} \mathrm{~N}_{4} \mathrm{O}_{6} \mathrm{SCu}$ (MW: $589.14 \mathrm{~g} / \mathrm{mol}$ ): C, 53.01; H, 4.96; N, 9.51; S, 5.44; O, 16.29; Cu, 10.79\% and found: C, 53.28; H, 5.02; N, 9.49; S, 5.52; O, 16.19; $\mathrm{Cu}, \quad 11.01 \% . \mathrm{MS} \quad(\mathrm{m} / \mathrm{z}, \quad$ (relative abundance, \%)): $589\left[\mathrm{M}^{+}, 13.7\right]$.

\section{Magnetic susceptibility}

The mixed ligand metal complexes had magnetic moments in the range of 1.71-3.79 B.M. $\mathrm{Zn}$ (II) complexes usually have distorted square planer configuration and a magnetic moment was 1.71 B.M. The $\mathrm{Ni}(\mathrm{II}), \mathrm{Co}(\mathrm{II})$ and $\mathrm{Cu}(\mathrm{II})$ complexes also support their octahedral geometry with magnetic moments of $3.42, \quad 3.21$ and 3.79 B.M, respectively.

\section{FT-IR studies}

The two main regions are of interest in mixed ligand complexes because they give valuable information about the coordination behavior of ligands to metals. These are $\mathrm{C}=\mathrm{N}$ and $\mathrm{S}=\mathrm{O}$ (sulphonic acid group). In the IR spectra of OMZ, a peak appeared at $3560 \mathrm{~cm}^{-1}$. This peak was due to the stretching vibration of $v(\mathrm{~N}-\mathrm{H})$ in benzimidazole. The stretching vibration of $\mathrm{C}=\mathrm{N}$ occurs at $1586 \mathrm{~cm}^{-1}$ while that of $\mathrm{S}=\mathrm{O}$ occurs at $1010 \mathrm{~cm}^{-1}$. In the case of 8-hydroxyquinoline (HQL) molecules, the stretching vibration of $v(\mathrm{CO})$ appears in medium peak at $1712 \mathrm{~cm}^{-1}$ whereas $v(\mathrm{C}=\mathrm{N})$ and $v(\mathrm{OH})$ stretching vibrations occur at $1643 \mathrm{~cm}^{-1}$ and $3453 \mathrm{~cm}^{-1}$, respectively.

In the FTIR spectra of the mixed ligand metal complexes, the stretching vibration of $v(\mathrm{~N}-\mathrm{H})$ of the benzimidazole appeared at $\sim 3060 \mathrm{~cm}^{-1}$, indicating its non-involvement in coordination with metal ions. The peaks for $v(\mathrm{~S}=\mathrm{O}$ ) (sulphonic acid group) appeared between 1023 and 1032 $\mathrm{cm}^{-1}$, with a shift of $13-22 \mathrm{~cm}^{-1}$ to the higher wave number relative to $\mathrm{OMZ}$, indicating the involvement of $\mathrm{S}=\mathrm{O}$ group in the coordination of the complexes. The region between 1559-1534 $\mathrm{cm}^{-1}$ was allocated to the $v(\mathrm{C}=\mathrm{N})_{\mathrm{bnz}}$ vibrations of all the complexes with shift of $27-52 \mathrm{~cm}^{-1}$ to the lower wave number, than $\mathrm{C}=\mathrm{N}$ bond become weak due to drm-prt (metal to ligand) back donation and it shifts to lower wave number which indicating its involvement in coordination with metal ions. In the case of stretching vibrations, $\quad v(\mathrm{C}=\mathrm{N})_{\mathrm{HQL}}$ appeared at 1623-1637 $\mathrm{cm}^{-1}$ but it also shift to lower wave number of 6 $20 \mathrm{~cm}^{-1}$.

The stretching vibration of $v(\mathrm{CO})$ (HQL) appeared between $1723-1733 \mathrm{~cm}^{-1}$, with shift of $11-21 \mathrm{~cm}^{-1}$ to the higher wave number, 
confirming attachment to metal ions. The shifting of peaks of the $\mathrm{C}=\mathrm{N}, \mathrm{S}=\mathrm{O}$ and $\mathrm{CO}$ on complexation gives valuable information about the point of attachment of metal ions to $\mathrm{OMZ}$ and 8- HQL; this also confirms that $\mathrm{OMZ}$ and $\mathrm{HQL}$ behave as bidentate ligands. In the case of HQL there is a considerable shift in the frequencies of $\mathrm{O}$ and $\mathrm{C}=\mathrm{N}$ group and also acting as a bidentate ligand due to coordination with metal in all the complexes. The broad-stretching vibration bands found within the range $3600-2700 \mathrm{~cm}^{-1}$ was assigned to the coordination of water molecules in the $\mathrm{Cu}(\mathrm{II})$ and $\mathrm{Ni}(\mathrm{II})$ complexes. New absorption bonds of $\mathrm{M}-\mathrm{O}$ stretching mode of vibration were assigned $479-488 \mathrm{~cm}^{-1}$ of the synthesized complexes, while M-N stretching vibration mode was assigned within the range of $435-449 \mathrm{~cm}^{-1}$.

\section{Electronic absorption spectra}

The absorption spectra of $2.5 \times 10^{-3} \mathrm{M}$ solutions of $\mathrm{OMZ}, \mathrm{HQL}$ and synthesized complexes in DMSO were recorded from 200 to $800 \mathrm{~nm}$ at room temperature. UV spectra showed high absorption intensity in ultraviolet (UV) region due to presence of benzimidazole chromosphere and these complexes are inactive in the visible region. Two strong bands were observed for $\mathrm{OMZ}$ at 257 and $300 \mathrm{~nm}$, and for 8hydroxyquinoline at 263 and $293 \mathrm{~nm}$. These bands were attributed to $n \rightarrow \pi^{*}$ and $\Pi \rightarrow \pi^{*}$ electronic transition in the framework of the synthesized complexes. In all the complexes, bands that commonly appeared in- between 289-
$343 \mathrm{~nm}$ were attributed to intra ligand transitions consistent with electronic transition of $\mathrm{C}=\mathrm{N}$ group. Upon complexation, the absorption bands of the complexes were slightly shifted to higher wavelength (red shift) compared to those of the free ligand omeprazole as well as 8hydroxyquinoline. These modifications of the shifts and intensities of the absorption bands indicate the coordination of the ligand to the metal ions. A square-planar arrangement around $\mathrm{Zn}$ (II) complex is supported due to occurrence of intermolecular charge transfer and ligand-tometal charge transfer (LMCT) at 289 and 229 $\mathrm{nm}$, respectively. However in Co (II), Ni (II) and $\mathrm{Cu}$ (II) complexes, the structural geometry is octahedral due to attachment of water molecule. This was confirmed by FT-IR spectra of these complexes.

\section{Morphological and structural properties of synthesized metal ligand complexes}

The morphological and structural properties of the mixed ligand metal complexes were evaluated using scanning electron microscopy (SEM). The SEM micrographs are shown in Figure 2. Zn (II) and Co (II) complexes showed particles with sizes in the nanometer range, and their structures are homogenous. Some Ni (II) and $\mathrm{Cu}$ (II) complexes were irregularly-shaped and well-separated from each other, while most are present in agglomerated forms. Thus, these SEM results confirmed the nano-structured behavior of the synthesized metal complexes.
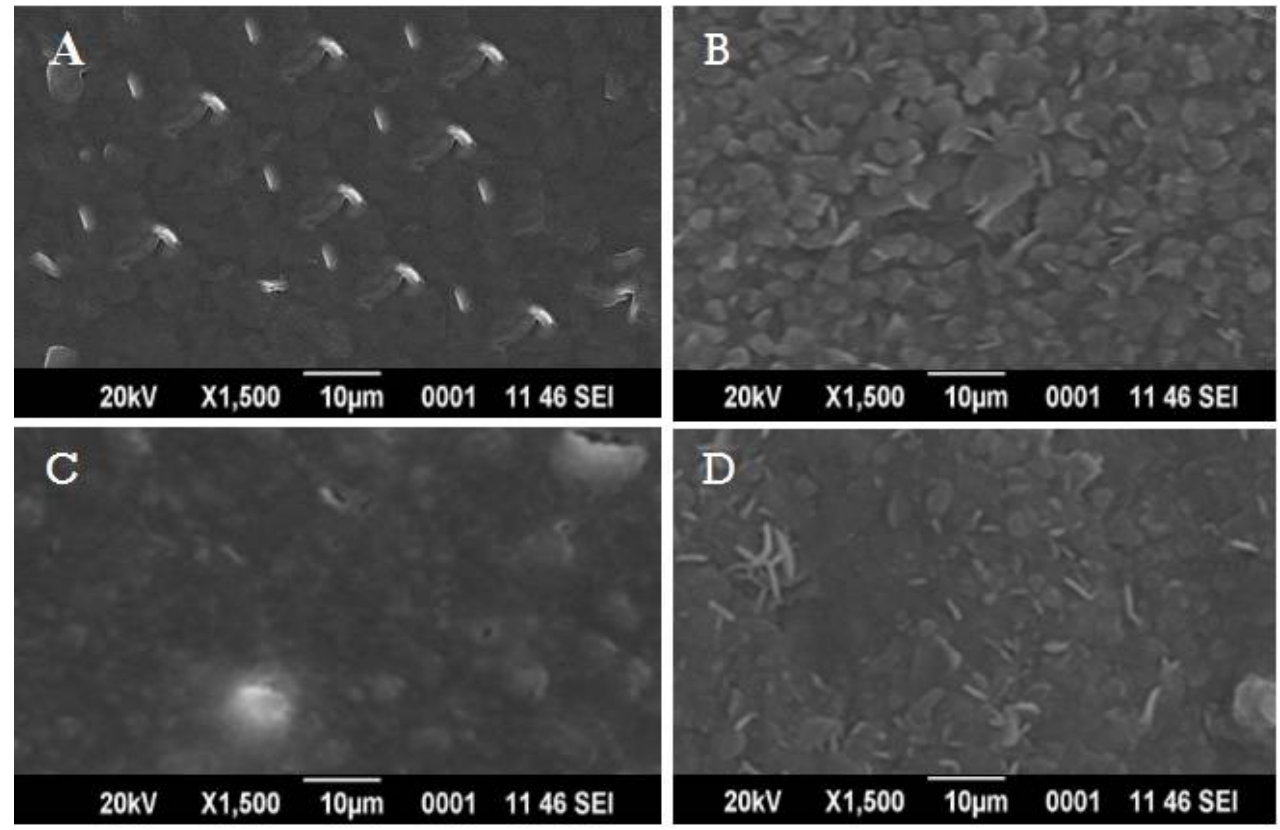

Figure 2: SEM images of mixed ligand metal complexes. $(A)=\mathrm{Zn}(\mathrm{II}) ;(\mathrm{B})=\mathrm{Co}(\mathrm{II}) ;(\mathrm{C})=\mathrm{Cu}(\mathrm{II})$ and $(\mathrm{D})$ $=\mathrm{Ni}(\mathrm{II})$ 


\section{${ }^{1}$ H NMR Spectra}

The ${ }^{1} \mathrm{H}$ NMR spectra of the synthesized mixed ligand complexes was obtained in deuterated DMSO- $d_{6}$. In ${ }^{1} \mathrm{H}$ NMR spectrum, the signal that appeared around the $\delta 3.42-3.51 \mathrm{ppm}$ was assigned to $\mathrm{O}-\mathrm{CH}_{3}$, while methylene $\left(-\mathrm{CH}_{2}\right)$ protons were responsible for the doublet peak at $\delta$ 4.64-4.69 ppm in all the synthesized complexes. The NMR signals for $\mathrm{CH}$ group were observed downfield in comparison to normal position because of the electron-withdrawing effect of neighboring atoms like nitrogen and oxygen in five-membered rings which make it more de-shielded.

There was a weak signal at $2.16 \mathrm{ppm}$ which may be assigned to the methyl $\left(-\mathrm{CH}_{3}\right)$ protons but its integration showed otherwise. It may be that it was unusually merged with the DMSO peak. Due to non-involvement of $\mathrm{NH}$ proton in coordination, the singlet peak was observed at $11.23 \mathrm{ppm}$ in all the synthesized complexes. The aromatic hydrogens were observed at $\delta 6.916-8.446 \mathrm{ppm}$. Figure 3 shows the ${ }^{1} \mathrm{H}$ NMR spectra of $\mathrm{Zn}$ (II) mixed ligand complex.

\section{Mass spectra}

The mass spectra were recorded for synthesized mixed ligand complexes at $300{ }^{\circ} \mathrm{C}$ and $70 \mathrm{eV}$. All the spectra exhibited parent peaks due to molecular ions. The proposed molecular formulae of these complexes were confirmed by comparing their molecular formula weights with $\mathrm{m} / \mathrm{z}$ values. Molecular ion peaks were observed in complexes of $\mathrm{Zn}$ (II), Ni (II), $\mathrm{Cu}$ (II) and Co (II) at $\mathrm{m} / \mathrm{z} 554, \mathrm{~m} / \mathrm{z} 584, \mathrm{~m} / \mathrm{z} 589, \mathrm{~m} / \mathrm{z} 584$, respectively. This was in line with the composition of synthesized complexes. Mass spectra of $\mathrm{Zn}$ (II) and $\mathrm{Ni}$ (II) complexes are shown in Figure 4 and Figure 5.

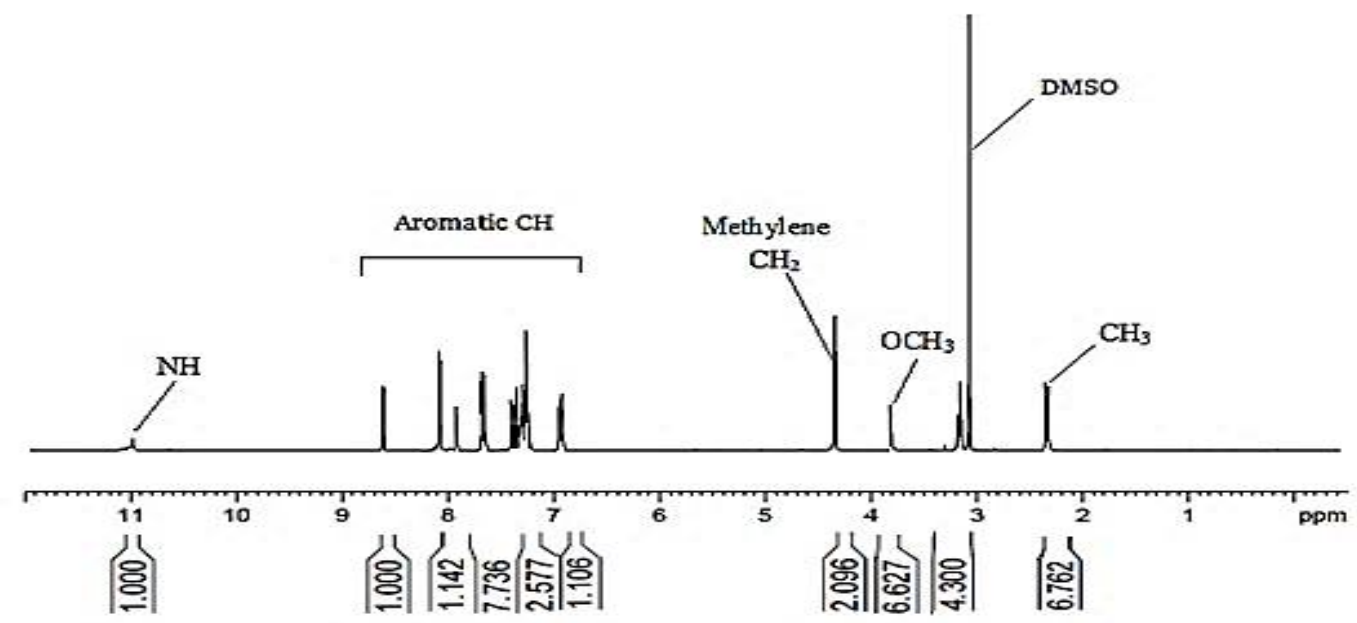

Figure 3: ${ }^{1} \mathrm{H}$ NMR spectra of Zn (II) mixed ligand complex

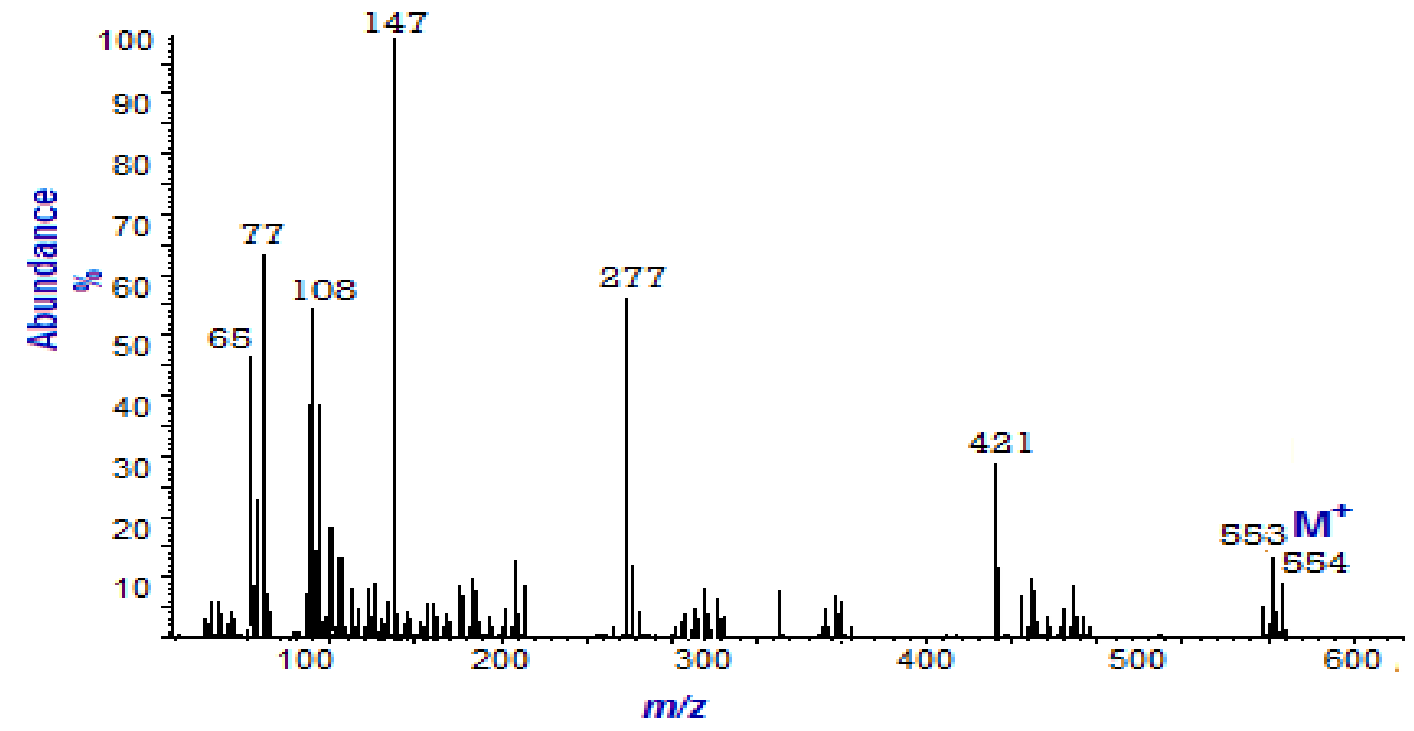

Figure 4: Mass spectra of Zn (II) mixed ligand Complex 


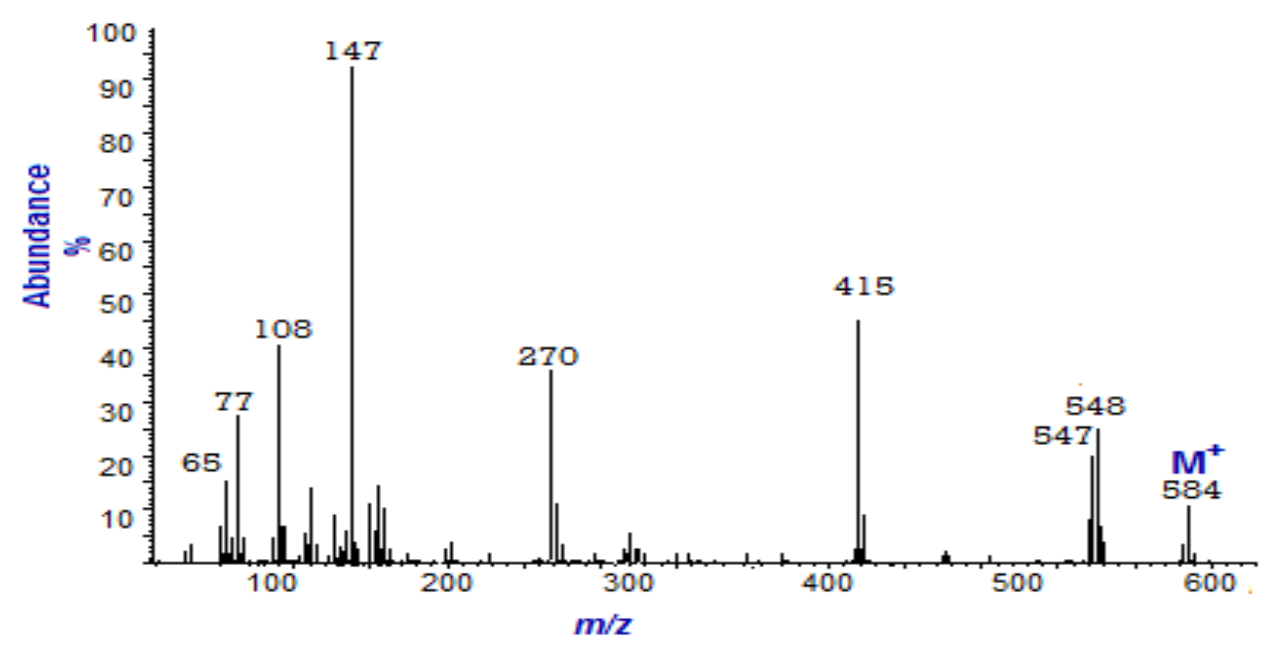

Figure 5: Mass spectra of $\mathrm{Ni}$ (II) mixed ligand complexes

\section{Inhibitory effects on ALPs activity}

OMZ, HQL and the mixed ligand complexes were examined for their inhibition against ALPs. All the synthesized complexes exhibited concentrationdependent inhibitory activities against ALPs. The exact mechanism involved in this inhibition is not clear. ALPs assay was carried out at different specimen concentrations $(0.24,0.48,0.73$ and $0.96 \mathrm{mM}$ ). Graphical representation of the effects of $\mathrm{OMZ}, \mathrm{HQL}$ and synthesized complexes on ALPs is shown on Figure 6. It was also found that at a concentration of $0.96 \mathrm{mM}$, ALPs inhibition ranged from 80 to $98 \%$ for all the complexes. Among the bimetallic complexes, the highest ALPs inhibition was observed with Ni (II) complex, followed by $\mathrm{OMZ}, \mathrm{HQL}$ and other complexes. The order of inhibition of ALPs by the synthesized compounds was $\mathrm{Zn}$ (II) $>\mathrm{Ni}(\mathrm{II})>$ $\mathrm{Co}(\mathrm{II})>\mathrm{Cu}(\mathrm{II})>\mathrm{OMZ}>\mathrm{HQL}$.

\section{DPPH radical scavenging activity}

$\mathrm{DPPH}$ is a stable organic compound and it is extensively used for oxidative assay of the proton-donation ability of the samples. The results of free radical scavenging ability of the tested compounds are shown in Figure 7. All the complexes showed good antioxidant activity with respect to DPPH scavenging potential. Ni (II) complex $\left(\mathrm{IC}_{50}=30.48 \pm 0.30\right)$ showed higher DPPH scavenging activity than $\mathrm{Zn}$ (II), Co (II) and $\mathrm{Cu}$ (II) complexes. Ni (II) complex was also better than BHT $\left(\mathrm{IC}_{50}=40.31 \pm 0.4166 \mu \mathrm{M}\right)$. The $\mathrm{Cu}$ (II) mixed ligand complex $\left(\mathrm{IC}_{50}=36.11 \pm 0.37\right)$ was active but had lower DPPH radicalscavenging activity than other synthesized complexes and BHT. The order of $\mathrm{DPPH}$ scavenging was $\mathrm{Ni}(\mathrm{II})>\mathrm{Co}(\mathrm{II})>\mathrm{Zn}(\mathrm{II})>\mathrm{Cu}(\mathrm{II})>$ $\mathrm{OMZ}>\mathrm{BHT}>\mathrm{HQL}$.

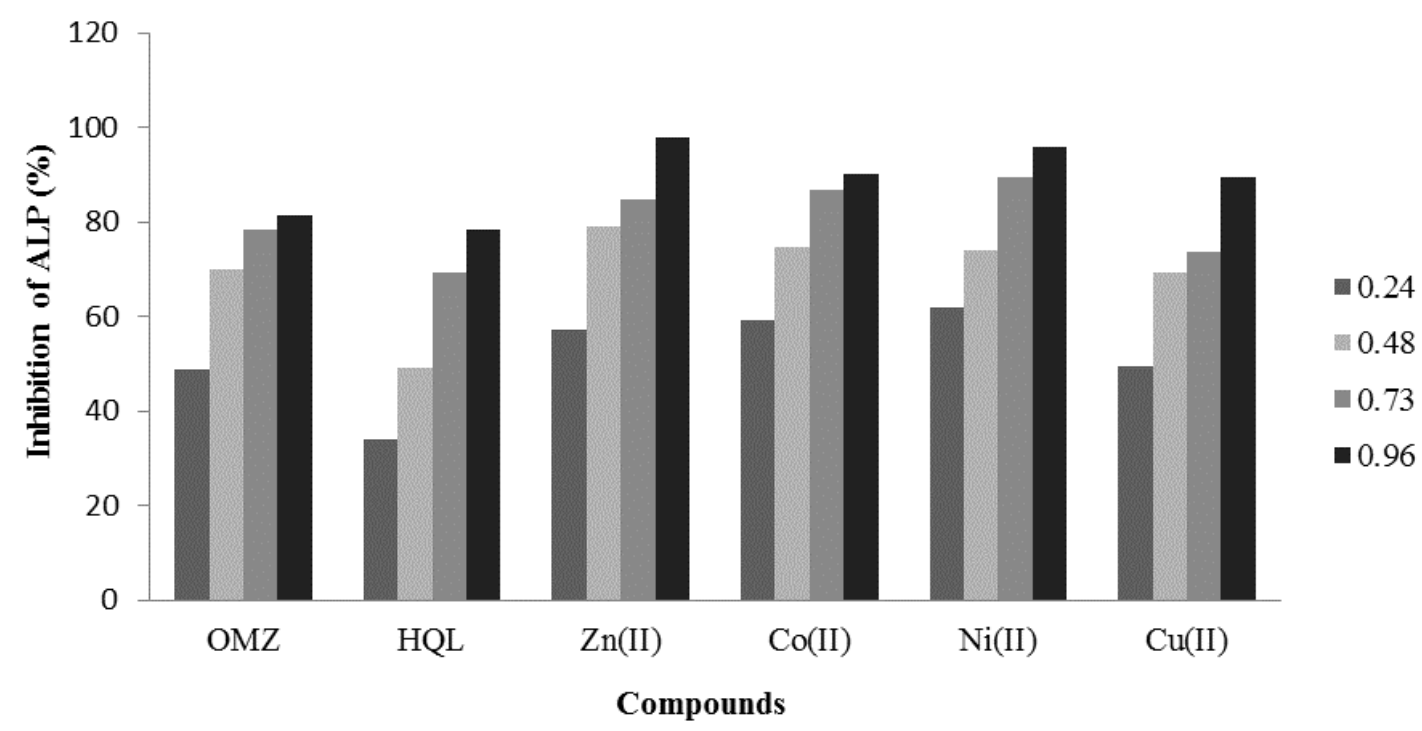

Figure 6: Inhibition of ALPs by OMZ, HQL and synthesized complexes 


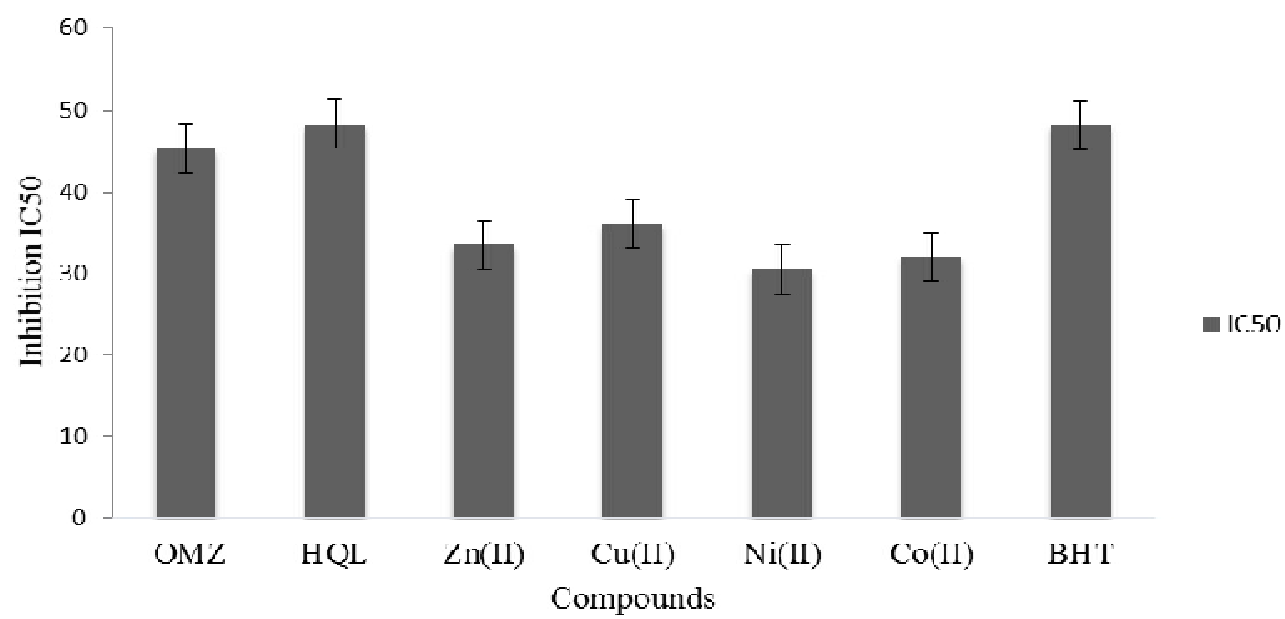

Figure 7: $I C_{50}$ values in DPPH radical scavenging activities of ligands and synthesized complexes

Antibacterial activities of synthesized metal ligand complexes

The antibacterial activity of OMZ, HQL and synthesized complexes were investigated against three gram-negative strains, $E$. coli, $P$. aeruginosa, and $K$. pneumoniae, as well as three gram-positive strains, $A$. viscosus, $S$. aureus and $B$. subtilis. $\mathrm{Cu}(\mathrm{II})$ complex had the largest zones of inhibition against E. coli, S. aureus and $A$. viscosus. $\mathrm{Ni}(\mathrm{II})$ complex produced the largest antibacterial activity against $P$. aeruginosa and $E$. coli. Zn (II) complex higher inhibition zones for $K$. pneumoiae than any of the other complexes or Ampicillin. The order of antibacterial activity of the compounds was $\mathrm{Cu}(\mathrm{II})>\mathrm{Ni}(\mathrm{II})>\mathrm{OMZ}>$ $\mathrm{Zn}(\mathrm{II})>\mathrm{HQL}>$ Ampicillin. The antibacterial effects of OMZ, HQL and synthesized complexes against both gram-negative and gram-positive microscopic organisms are shown in Table 1.

\section{Antifungal activity of synthesized complexes}

The antifungal activities of OMZ, HQL and synthesized complexes were determined against three parasitic strains: $C$. albicans, $A$. flavus, and
A. niger. The complexes showed highest antifungal activity against fungal strains due to presence of $\mathrm{S}=\mathrm{O}$ and $\mathrm{C}=\mathrm{N}$ groups in their structures. Zn (II) complex showed the highest zones of inhibition against $C$. albicans and $A$. niger, while Co (II) complex had the highest activity against $C$. albicans and $A$. flavus. Cu (II) complex was more active against $A$. niger but lower in activity than OMZ. The order of antifungal activity of the compounds was $\mathrm{Zn}(\mathrm{II})$ $>\mathrm{Co}$ (II) >Ni(II) >Cu(II) >OMZ > $\mathrm{HQL}>$ Fluconazole. The antifungal activity of $\mathrm{OMZ}, \mathrm{HQL}$ and synthesized complexes are shown in Table 2.

\section{DISCUSSION}

In the present study, new and mixed ligand metal complexes were synthesized, and characterized by elemental analysis, conductance measurements, UV-visible, Mass spectra, SEM, $\mathrm{IR}$ and ${ }^{1} \mathrm{H}$-NMR.The major absorption bands in FTIR spectrum appeared at $U_{\max } \mathrm{Cm}^{-1} 1023-1032$ ( $\mathrm{S}=\mathrm{O}$, str.), 1559-1534 ( $\mathrm{C}=\mathrm{N}$, str. $)_{\mathrm{bnz}}$ and 16231637 for $(\mathrm{C}=\mathrm{N}, \mathrm{str} \text {. })_{\mathrm{HQL}}$. Stretching vibration of

Table 1: Zones of inhibitions of OMZ, HQL and synthesized mixed ligand complexes (100 $\mu \mathrm{g} / \mathrm{mL})$ against bacterial strains

\begin{tabular}{|c|c|c|c|c|c|c|}
\hline \multirow{3}{*}{ Compound } & \multicolumn{6}{|c|}{ Zone of Inhibition (mm) } \\
\hline & \multicolumn{3}{|c|}{ Gram positive bacteria } & \multicolumn{3}{|c|}{ Gram negative bacteria } \\
\hline & $\begin{array}{l}\text { Bacillus } \\
\text { subtilis }\end{array}$ & $\begin{array}{l}\text { Staphylococcus } \\
\text { aureus }\end{array}$ & $\begin{array}{l}\text { Actinomyces } \\
\text { viscosus }\end{array}$ & $\begin{array}{l}\text { Pseudomonas } \\
\text { aeruginosa }\end{array}$ & $\begin{array}{l}\text { Klebsiella } \\
\text { pneumoniae }\end{array}$ & $\begin{array}{l}\text { Escherichia } \\
\text { coli }\end{array}$ \\
\hline OMZ & $23 \pm 0.21$ & $21 \pm 0.03^{*}$ & $19 \pm 0.34$ & $19 \pm 0.36$ & $21 \pm 0.23$ & $23 \pm 0.26$ \\
\hline $\mathrm{HQL}$ & $18 \pm 0.14$ & $19 \pm 0.46$ & $16 \pm 0.61$ & $16 \pm 0.41^{*}$ & $14 \pm 0.72^{*}$ & $17 \pm 0.63$ \\
\hline $\mathrm{Zn}(\mathrm{II})$ & $21 \pm 0.25^{\star}$ & $19 \pm 0.23^{*}$ & $18 \pm 0.46$ & $17 \pm 0.37$ & $19 \pm 0.31$ & $21 \pm 0.27$ \\
\hline Co (II) & $19 \pm 0.37$ & $24 \pm 0.32^{*}$ & $17 \pm 0.61$ & $24 \pm 0.21^{*}$ & $19 \pm 0.34$ & $23 \pm 0.23$ \\
\hline $\mathrm{Ni}(\mathrm{II})$ & $19 \pm 0.32$ & $20 \pm 0.33^{*}$ & $19 \pm 0.56$ & $29 \pm 0.14$ & $24 \pm 0.20$ & $28 \pm 0.09^{*}$ \\
\hline $\mathrm{Cu}(\mathrm{II})$ & $21 \pm 0.25^{*}$ & $30 \pm 0.11$ & $29 \pm 0.34^{*}$ & $27 \pm 0.16$ & $25 \pm 0.23$ & $28 \pm 0.06^{*}$ \\
\hline *Ampicillin & $14 \pm 0.43$ & $16 \pm 0.37$ & $15 \pm 0.46$ & $14 \pm 0.52$ & $13 \pm 0.73$ & $15 \pm 0.41$ \\
\hline
\end{tabular}


Table 2: Zones of inhibition of OMZ, HQL and synthesized mixed ligand complexes $(100 \mu \mathrm{g} / \mathrm{mL})$ against the fungal strains

\begin{tabular}{llcl}
\hline Compounds & \multicolumn{3}{c}{ Zone of inhibition (mm) } \\
\cline { 2 - 4 } & Aspergillus nigar & Aspergillus flavus & Candida albicans \\
\hline OMZ & $18 \pm 0.33$ & $17 \pm 0.52$ & $21 \pm 0.24$ \\
HQL & $14 \pm 0.54$ & $16 \pm 0.63$ & $13 \pm 0.52$ \\
Zn (II) & $21 \pm 0.25$ & $25 \pm 0.13$ & $27 \pm 0.13$ \\
Co (II) & $21 \pm 0.23$ & $19 \pm 0.41$ & $16 \pm 0.53$ \\
$\mathrm{Ni}$ (II) & $24 \pm 0.13$ & $23 \pm 0.24$ & $18 \pm 0.36$ \\
$\mathrm{Cu}$ (II) & $13 \pm 0.72$ & $16 \pm 0.54$ & $19 \pm 0.33$ \\
'FLuconazole & $12 \pm 0.68$ & $14 \pm 0.50$ & $11 \pm 0.61$ \\
\hline & standard drug; the diameter of inhibition zones are means of triplicate determinations \pm SEM.
\end{tabular}

$v(\mathrm{CO})_{\mathrm{HQL}}$ appeared at $1723-1733 \mathrm{~cm}^{-1}$. This confirms coordination behavior with metal ions [19-22]. FTIR spectroscopy showed that OMZ and $\mathrm{HQL}$ acted as neutral bidentate ligands. The $\lambda_{\max }$ of OMZ was observed at 257 and $300 \mathrm{~nm}$, and at 263 and $293 \mathrm{~nm}$ for 8-hydroxyquinoline. These absorption peaks are due to $n \rightarrow \pi^{*}$ and $\pi \rightarrow \pi^{*}$ electronic transition [23]. The electronic spectra of the synthesized mixed ligand complexes were in the range of 300-350 $\mathrm{nm}$. The presence of aliphatic and aromatic protons in the mixed ligand complexes was observed within the expected areas of the proton NMR spectra. The proposed structures of these complexes were confirmed by comparing their molecular formula weights with $\mathrm{m} / \mathrm{z}$ values. The magnetic moment of all the synthesized complexes were observed in the range of 1.71 . 3.79 B.M. Spectroscopic studies used to verify the chemical composition of products (as well as geometry of the complexes and molar conductance) indicated that the synthesized metal complexes were non-electrolytes in nature. The complexes, at 0.96 mM exhibited 80-98\% inhibition of ALPs [17]. Zn(II) complex was more active against the enzyme than $\mathrm{OMZ}, \mathrm{HQL}$ and other complexes. All the complexes showed higher antioxidant activity when compared to OMZ, HQL and BHT. The DPPH radical scavenging activity of $\mathrm{Ni}(\mathrm{II})$ complex $\left(\mathrm{IC}_{50}=\right.$ $30.48 \pm 0.3031)$ was highest when compared with those of $\mathrm{Ni}(\mathrm{II}), \mathrm{Co}(\mathrm{II})$ and $\mathrm{Cu}(\mathrm{II})$ complexes, as well as $\mathrm{BHT}\left(\mathrm{IC}_{50}=40.31 \pm 0.42 \mu \mathrm{M}\right)$ [24]. Cu (II) complex had the highest antibacterial activity against the bacterial strains, while $\mathrm{Zn}$ (II) complex had the highest antifungal activity against the fungal species.

\section{CONCLUSION}

A new series of mixed ligand complexes have been successfully synthesized and characterized by spectroscopic techniques. All the synthesized metal complexes possessed good antioxidant and antimicrobial properties. All the mixed ligand complexes demonstrated higher antioxidant, ALPs-inhibitory and antimicrobial activities than their corresponding ligands. This indicates their enormous therapeutic potential as future drug candidates for different diseases.

\section{DECLARATIONS}

\section{Acknowledgement}

This work was supported by the Department of Chemistry, School of Science, University of Management and Technology, Lahore, Pakistan.

\section{Conflict of Interest}

No conflict of interest associated with this work.

\section{Contribution of Authors}

The authors declare that this work was done by the authors named in this article and all liabilities pertaining to claims relating to the content of this article will be borne by them.

\section{Open Access}

This is an Open Access article that uses a funding model which does not charge readers or their institutions for access and distributed under the terms of the Creative Commons Attribution License (http://creativecommons.org/licenses/by/ 4.0) and the Budapest Open Access Initiative (http://www.budapestopenaccessinitiative.org/rea d), which permit unrestricted use, distribution, and reproduction in any medium, provided the original work is properly credited.

\section{REFERENCES}

1. Bruni AT, Ferreira MRMC. Theoretical study of omeprazole behavior: Racemization barrier and decomposition reaction. Int J Quantum Chem 2008; 108: 1097-1106.

2. Souney PF, Matthews SJ. In Comprehensive Pharmacy Review, pp. 765-777, Harwal, 2nd edition, 1994. 
3. Munson K, Garcia R, Sachs G. Inhibitor and ion binding sites on the gastric H,K-ATPase. Biochemistry 2005; 44 : 5267-5284.

4. Massoomi F, Savage J, Destache CJ. Omeprazole: a comprehensive review. Pharmacotherapy 1993; 13: 4659.

5. Wallmark B, Brandstrom A, Larsson H. Evidence for acidinduced transformation of omeprazole into an active inhibitor of $\mathrm{H}+, \mathrm{K}+$-ATPase within the parietal cell. Biochim Biophys Acta 1984; 778: 549-558.

6. Kobayashiv K, Yamamoto T, Chiba K, Tani M, Ishizaki T, Kuroiwa $Y$. The effects of selective serotonin reuptake inhibitors and their metabolites on S-mephenytoin 4'hydroxylase activity in human liver microsomes. $\mathrm{Br} J$ Clin Pharmacol 1995; 40: 481-485.

7. Gata L, Perna F, Figura N, Ricci C, Holton J, Danna L, Miglioli M.D, Vaira. Antimicrobial activity of esomeprazole versus omeprazole against Helicobacter pylori. J Antimicrob Chemother 2003; 51: 439-444.

8. Jonkers $D$, Stobberingh E, Stockbrugger R. Omeprazole inhibits growth of Gram-positive and Gram-negative bacteria including Helicobacter pylori in vitro. J Antimicrob Chemother 1996; 37: 145-150.

9. Russo MG, Hissi EGV, Rizzi AC, Brondino CD, Ibanez AGS, Vega $A E$, Silva HJ, Mercader R, Narda GE. Synthesis, physicochemical characterization, DFT calculation and biological activities of $\mathrm{Fe}$ (III) and $\mathrm{Co}$ (II)omeprazole complexes. Potential application in the Helicobacter pylori eradication. J Mol Struct 2014; 10(61): 5-13.

10. Bosch ME, Sanchez AJR, Rojas FS, Ojeda CB. Analytical methodologies for the determination of omeprazole: an overview. J Pharm Biomed Anal 2007; 44(4): 831-844.

11. Cheatum CM, Heckscher MN, Crim FF, Excited-state dynamics in 8-hydroxyquinoline dimmers. Crim Chem Phys Lett 2001; 349: 37-42

12. Malik MR, Vasylyeva V, Merz K, Metzler-Nolte N, Saleem M, Ali S, Ahmad S. Synthesis, crystal structures, antimicrobial properties and enzyme inhibition studies of zinc(II) complexes of thiones. Inorg. Chim Acta 2011; 376: 207-211.

13. Ogunniran KO, Tella AC, Alensela M, Yakubu MT. Synthesis, physical properties, antimicrobial potentials of some antibiotics complexed with transition metals and their effects on alkaline phosphatase activities of selected rat tissues. Afr J Biotechnol 2007; 6(10): 12021208.
14. Khan SA, Rasool N, Riaz M, Nadeem R, Rashid U, Rizwan K, Zubair M, Bukhari IH, Gulzar T. Evaluation of Antioxidant and Cytotoxicity Studies of Clerodendrum inerme. Asian J Chem 2013; 13: 7457-7462.

15. Noipa T, Srijaranai S, Tuntulani T, Ngeontae W. New approach for evaluation of the antioxidant capacity based on scavenging DPPH free radical in micelle systems. Food Res Int 2011; 44(3): 798-806.

16. Khan $S A$, Shahid $S$, Jameel M, Ahmad A. In vitro Antibacterial, Antifungal and GC-MS Analysis of seeds of Mustard Brown. Int J Pharm Chem 2016; 6(4): 107115.

17. Hussain S, Ali S, Shahzadi S, Shahid M. Heterobimetallic complexes containing $S n(I V)$ and Pd(II) with 4-(2Hydroxyethyl)piperazine-1-carbodithioic acid: Synthesis, characterization and biological activities. Cogent Chemistry 2015; 1: 1-13.

18. Nakao M, Tada M, Tsuchimori K, Uekata M. Antibacterial properties of lansoprazole alone and in combination with antimicrobial agents against Helicobacter pylori. Eur $J$ Clin Microbiol Infect Dis 2005; 14: 391-399.

19. Das S, Malliik S, Jaiin B. Physicochemical characterization and synthesis of transitions metal complex of omeprazole. Int J Ad Sci Techni Res 2014; 4(4): 519-525.

20. Krishnakumar V, Ramasay R. DFT studies and vibrational spectra of isoquinoline and 8hydroxyquinoline. Spectrochim Acta A 2005; 61(4): 673683.

21. Mohamed GG, Nour-el-dien FA, Khalil SM, Mohammad AS, Metal complexes of omeprazole. Preparation, spectroscopic, thermal characterization and biological activity. J Coord Chem 2009; 62(4): 645-654.

22. Verma S, Shrivastva S, Rani P. Synthesis and physicochemical studies of newly formed complexes of transition and inner transition metlas with (5-methoxy-2$\{\{(4-m e t h o x y-3,5-$ dimethy-1-pyridiny) methyl\}sulfinyi\}IH-benzimidazole). Der Chemica Sinica 2011; 2(5): 1221.

23. Malik $S$, DAS $S$, Jain B. First- row transition metal complexes of omeprazole as anti-ulcerative drugs. Indo J Chem 2010; 10(3): 382-389.

24. Noipa T, Srijaranai S, Tuntulani T, Ngeontae W. New approach for evaluation of the antioxidant capacity based on scavenging DPPH free radical in micelle systems. Food Res Int 2011; 44(3): 798-806. 